\title{
Laboratory-scale smelting of limonitic laterite ore from Central Anatolia
}

\author{
by S. Pournaderi*, E. Keskinkılıç ${ }^{\dagger}$, A. Geveci ${ }^{\ddagger}$, and
}

Y.A. Topkaya ${ }^{\ddagger}$

\section{Synopsis}

The feasibility of ferronickel production from a low-grade limonitic laterite ore was investigated. The ore was first calcined and then prereduced in the solid state. The reduced ore was then smelted to produce ferronickel. The effects of coal addition, smelting temperature, and retention time on the process were investigated. Chemical and physical losses in the slag were separately quantified. Coal addition was the main parameter that controlled the ferronickel grade and losses in the slag. The melting point of the slag was well below that of the ferronickel, which enhanced metal-slag separation and minimized physical losses in the slag. A microstructural study of an industrial slag revealed that $\mathrm{Cr}$-rich particulates, which were suspended in the slag, were mainly responsible for the physical losses in the slag.

Keywords

ferronickel, limonite, physical loss, chemical loss, slag.

\section{Introduction}

Nickel laterites are classified into three main types; saprolite, nontronite, and limonite. Of these, limonitic ores possess the lowest nickel content, ranging from 0.8 to $1.5 \mathrm{wt} \%$. It is generally accepted that limonitic laterites are suitable for hydrometallurgical treatment while saprolitic laterites are suitable for pyrometallurgical treatment, i.e. ferronickel smelting. However, this perception is changing and new projects (Reinecke and Lagendijk, 2007) are aiming to treat low-grade limonitic ores by pyrometallurgical routes (Mudd, 2010) to produce ferronickel. The simplicity of the process, the nickel market, and new advances in furnace technology, as briefly discussed below, are the main incentives for smelting of limonitic laterites.

Nickel in limonitic laterites is incorporated in minerals containing elements such as Fe, $\mathrm{Co}, \mathrm{Si}$, and $\mathrm{Mg}$. Hydrometallurgical methods basically handle the separation of nickel from these elements through a complex process to obtain nickel in pure form (Canterford, 1975). Pyrometallurgical processing is simpler and shorter as the product contains $\mathrm{Ni}, \mathrm{Fe}, \mathrm{Co}$, and $\mathrm{Cu}$.

The nickel market is the other incentive for ferronickel smelting from limonitic laterites. About $70 \%$ of this nickel output is used in iron-nickel based alloys such as stainless steels (Zevgolis, 2004), where Ni is added to the bath of molten alloy as ferronickel rather than high-priced metallic nickel. Hence separation of nickel from iron through the longer and more complicated

hydrometallurgical processes is not necessary. In addition, the growing demand for ferronickel and the gradual decline in highgrade saprolitic reserves will inevitably shift the industry towards the smelting of low-grade limonitic ores in the future.

Furthermore, recent advances in furnace technology (Walker et al., 2009; Voermann et al., 2004) have overcome, to a great extent, difficulties related to the smelting of limonitic ores, such as unfavourable slag composition and high $\mathrm{CO}_{2}$ emissions. Energy costs per ton of metal have decreased, thus compensating for the low grades of limonitic ores. With current technology and nickel market conditions, ores with a nickel content of more than $1 \%$ can be treated economically (Norgate, 2010). In the future, however, higher Ni prices and new advances could lower the cut-off grades.

This study investigated the feasibility of ferronickel production from a low-grade limonitic laterite ore. At the same time, it focused on the nickel losses in the slag, which is one of the major problems in ferronickel smelting. Ferronickel slags typically contain $0.1-0.2 \% \mathrm{Ni}$ and the nickel partition ratio (percentage $\mathrm{Ni}$ in the ferronickel divided by percentage $\mathrm{Ni}$ in the slag) is about 200 or

* Department of Metallurgical and Materials Engineering, Karadeniz Technical University, Trabzon, Turkey.

+ Department of Metallurgical and Materials Engineering, Attlim University, Incek, Ankara Turkey.

¥ Department of Metallurgical and Materials Engineering, Middle East Technical University, Ankara, Turkey.

(c) The Southern African Institute of Mining and Metallurgy, 2017. ISSN 2225-6253. Paper received Jul 2016; revised paper received Nov. 2016. 


\section{Laboratory-scale smelting of limonitic laterite ore from Central Anatolia}

greater (Warner, et al., 2006). Nonetheless, the Ni recovery does not exceed $95 \%$ at best because of the high volumes of ferronickel slags. Laterites are not amenable to concentration and all the ore, consisting of mainly gangue minerals, has to be processed. Therefore, regardless of laterite type, ferronickel smelting generates large volumes of slag (10-5 t of slag per ton ferronickel). Although many studies have been conducted on the smelting of laterites, nickel losses in the slag have not been adequately addressed and remain a challenge for the industry. An innovative method was used in this study for the first time to separately quantify the chemical and physical losses in the slag.

\section{Experimental}

\section{Raw materials}

Limonitic laterite ore from the Sivrihisar region in Turkey was used in the study. The run-of-mine (ROM) ore was screened at $50 \mathrm{~mm}$ to reject large Ni-deficient rocks. The undersize fraction was crushed to $-1 \mathrm{~mm}$, which was used in the experiments. The chemical composition of the $-50 \mathrm{~mm}$ ore, determined by inductively coupled plasma-atomic emission spectrometry (ICP-AES), is given in Table I.

Ukrainian coal was used as reductant. The particle size of the coal was reduced to $-1 \mathrm{~mm}$ in accord with that of the ore. The net calorific value and chemical analysis of the coal are given in Table II.

\section{Experimental procedure}

The ore was calcined and prereduced prior to smelting. An externally controlled muffle furnace was used for calcination. The sample was heated at $700^{\circ} \mathrm{C}$ for 40 minutes in air to completely remove chemically bound water and other volatiles. A vertical tube furnace was used for prereduction. Forty grams of calcined ore was mixed with a specified amount of coal and charged into a cylindrical alumina crucible. The sample was reduced at $1000^{\circ} \mathrm{C}$ for 40 minutes. A gas mixture consisting of $70 \% \mathrm{~N}_{2}-20 \% \mathrm{CO}_{2}-10 \% \mathrm{CO}$ was passed through the furnace at a flow rate of $50 \mathrm{ml} / \mathrm{min}$. Further information on the calcination and prereduction

\section{Table I}

Chemical composition of the $\mathbf{- 5 0} \mathrm{mm}$ ore (wt\%)

\begin{tabular}{|l|c|c|c|c|c|c|c|}
\hline $\mathbf{N i}$ & $\mathrm{Co}$ & $\mathrm{Fe}$ & $\mathrm{SiO}_{2}$ & $\mathrm{MgO}$ & $\mathrm{Cr}$ & $\mathrm{CaO}$ & $\mathrm{Al}_{2} \mathrm{O}_{3}$ \\
\hline 1.405 & 0.093 & 33.7 & 25.8 & 1.29 & 1.26 & 1.65 & 3.23 \\
\hline $\mathrm{MnO}$ & $\mathbf{A s}$ & $\mathrm{P}_{2} \mathrm{O}_{5}$ & $\mathbf{S}$ & $\mathrm{Cu}$ & $\mathrm{TiO}_{2}$ & $\mathbf{Z n}$ & $\mathbf{K}$ \\
\hline 0.74 & 0.04 & 0.04 & 0.03 & 0.006 & 0.08 & 0.03 & 0.2 \\
\hline
\end{tabular}

behaviour of the ore has been published previously (Keskinkılıç et al., 2012; Pournaderi et al., 2014).

The prereduced ore was then smelted at a desired temperature to obtain ferronickel, using the same furnace and crucible as used in the prereduction stage. The sample was retained at the smelting temperature for a predetermined time and then cooled to room temperature. No further coal was added in the smelting step and the reduction process was completed by the remaining (unreacted) coal from the prereduction stage. During smelting, a gas mixture consisting of $\mathrm{CO}(20 \mathrm{ml} / \mathrm{min})$ plus $\mathrm{CO}_{2}(10 \mathrm{ml} / \mathrm{min})$ was passed through the furnace. Details of the gas supply system and the vertical tube furnace are given in the following section. At the end of each experiment, the crucible was broken to remove slag and metal. Various views of a typical smelted sample are shown in Figure 1.

\section{Experimental set-up}

The gas supply system is schematically presented in Figure $2 \mathrm{a}$. The system consisted of three manometers and capillary tubes. A manometer is shown in detail in Figure $2 b$. The height of the coloured liquid (an aqueous solution of $\mathrm{KMnO}_{4}$ ) in the column controlled the gas flow through the capillary tube; the greater the height of liquid in the column, the higher the gas flow rate through the capillary tube. The gas mixture was sent to the vertical tube furnace, which is schematically shown in Figure 3.

High-purity nitrogen (99.99\%) and carbon dioxide (99.5\%) gases were used. Carbon monoxide gas was purified by passing it over copper chips at $500^{\circ} \mathrm{C}$.

\section{Chemical analysis}

The ferronickel button (see Figure 1) was readily obtained after breaking the crucible. The sample was prepared by standard metallographic methods and analysed by X-ray fluorescence (XRF). The carbon and sulphur contents were determined using a carbon/sulphur combustion analyser. Slag was obtained as lumps which were crushed and ground for X-ray diffraction (XRD) and chemical analyses. Prior to the grinding, metallographic sections of some slag lumps were prepared and investigated using scanning electron microscopy (SEM).

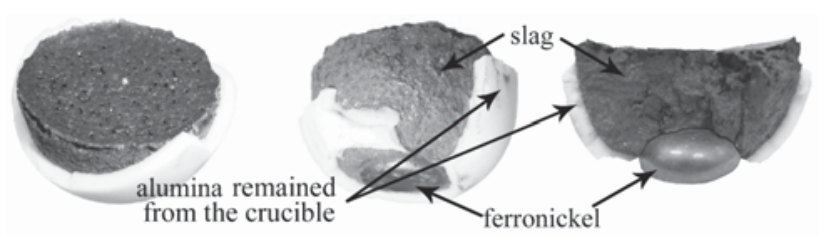

Figure 1-Photographs of a typical metal-slag sample obtained at the end of the smelting experiments

\section{Table II}

Net calorific value and chemical analysis (wt \%) of the Ukrainian coal used in the study

\begin{tabular}{|c|c|c|c|c|c|}
\hline Ash (mainly $\mathrm{SiO}_{2}$ ) & Volatile matter & Sulphur & Moisture & Fixed carbon & Net calorific value (kcal/ $/ \mathrm{kg})$ \\
\hline $\begin{array}{l}\text { ASTM D3174 } \\
4.2\end{array}$ & $\begin{array}{c}\text { ASTM D3175 } \\
17.64\end{array}$ & $\begin{array}{c}\text { ASTM D4239 } \\
0.33\end{array}$ & $\begin{array}{c}\text { ASTM D3302 } \\
1.77\end{array}$ & balance & $\begin{array}{c}\text { ASTM D5865 } \\
7752\end{array}$ \\
\hline
\end{tabular}




\section{Laboratory-scale smelting of limonitic laterite ore from Central Anatolia}

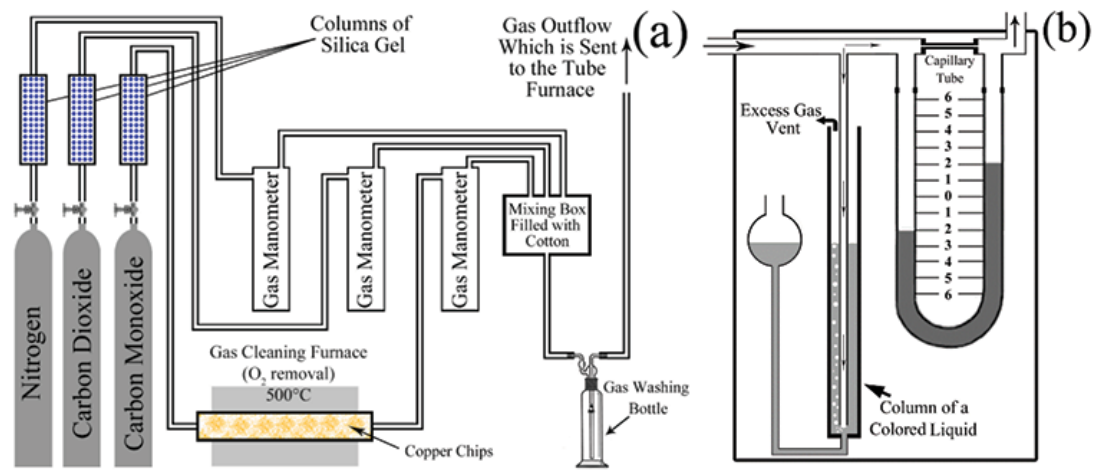

Figure 2-(a) General view of the gas supply, (b) detail of gas manometer

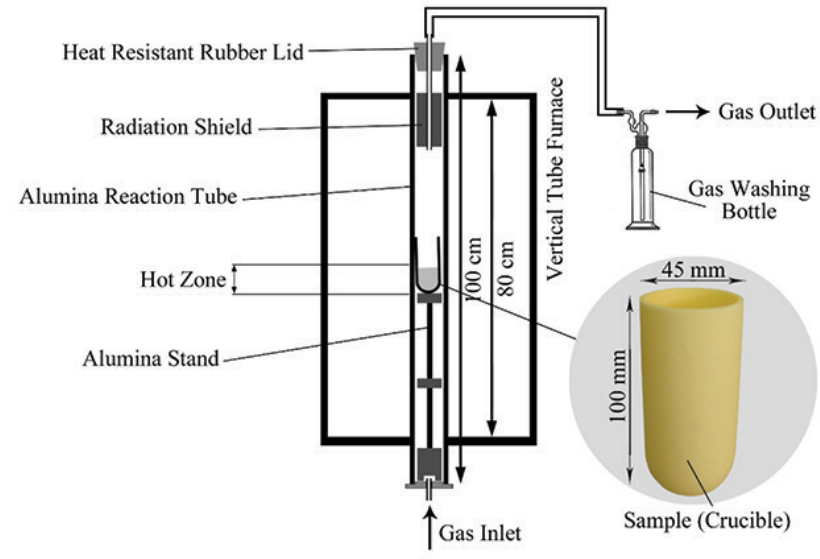

Figure 3-Schematic diagram of the vertical tube furnace and the crucible used in the smelting experiments

The chemical composition of the slag was determined by XRF. However, it was not possible to distinguish between different oxidation states of the same elements (e.g. $\mathrm{Fe}^{3+}$ and $\mathrm{Fe}^{2+}$ ) by XRF. This is particularly crucial in the current study, since it is required to separately measure physical $\left(\mathrm{Ni}^{\circ}\right)$ and chemical $\left(\mathrm{Ni}^{2+}\right)$ losses of nickel in the slag.

A unique two-step wet chemical technique was used to separately measure the physical and chemical losses of nickel in the slag. In the first step, physical losses were determined by extraction of the metallic phases with bromine-methanol solution (Pournaderi et al., 2014; Kinson, Dickeson, and Belcher, 1968) and measurement of the dissolved metals by atomic absorption spectrophotometry (AAS). In the second step, the residue from the first step was dissolved in an acid mixture $\left(\mathrm{HNO}_{3}+\mathrm{HCl}+\mathrm{HF}\right)$ and the solution was analysed by AAS to determine the chemical losses in the slag.

\section{Results and discussion}

\section{Effect of coal addition}

The effect of coal addition on the ferronickel grade and losses in the slag was investigated using $0,7.5,12.5$, and $17.5 \%$ in excess of the theoretical amount of coal required in the prereduction stage to reduce all of the ferric iron (haematite) to the ferrous state (wüstite) and all of the Ni and Co oxides to the metallic form. The aim was to maximize $\mathrm{Ni}+\mathrm{Co}$ metallization while limiting the metallization of iron, thereby ensuring a high-grade ferronickel product in the subsequent smelting step. Chemical analysis of the prereduced samples revealed that, depending on the coal amount, about 50-60\% of nickel and cobalt, and 5-10\% of iron, was reduced to the metallic form. The prereduced samples were smelted at $1500^{\circ} \mathrm{C}$ and retained for 30 minutes at this temperature.

The chemical compositions of the ferronickel products are given in Table III. The major constituents were $\mathrm{Fe}, \mathrm{Ni}$, and $\mathrm{Co}$, with low amounts of $\mathrm{C}$ and impurities (mainly As and $\mathrm{S}$ ). Trace amounts of $\mathrm{Cu}, \mathrm{Si}, \mathrm{Al}$, and $\mathrm{P}$ were also detected but are not included in the analyses. The reduction of $\mathrm{Cr}, \mathrm{Al}$, and $\mathrm{Si}$ oxides during ferronickel smelting is very limited because ferronickel slags contain significant amounts of a less stable oxide, i.e. iron oxide. Only $\mathrm{P}, \mathrm{S}, \mathrm{Cu}$, and $\mathrm{As}$ can be readily reduced and thus are expected to enter ferronickel. $\mathrm{P}$ and $\mathrm{S}$ are eliminated in the refining step in the industrial process. Copper does not cause any problems, but a high As $(>0.15 \%)$ content is not acceptable in the stainless steel industry (Zevgolis, 2004). Arsenic may be effectively

Table III

Chemical composition of the ferronickel products

\begin{tabular}{|l|c|c|c|c|c|c|c|c|c|c|}
\hline \multirow{2}{*}{ Exp. no. } & \multicolumn{3}{|c|}{ Experimental conditions } & \multicolumn{4}{c|}{ Ferronickel composition (wt.\%) } \\
\cline { 2 - 10 } & Temperature $\left({ }^{\circ} \mathbf{C}\right)$ & Retention time (min) & Excess coal (\%) & Ni & Co & As & Cr & S & C & Fe \\
\hline 1 & 1500 & 30 & 0 & 16.63 & 1.02 & 0.33 & 0.08 & 0.0690 & 0.0830 & Balance \\
2 & 1500 & 30 & 7.5 & 15.58 & 0.94 & 0.31 & 0.08 & 0.0766 & 0.0731 & Balance \\
3 & 1500 & 30 & 12.5 & 13.45 & 0.85 & 0.23 & 0.06 & 0.0691 & 0.0756 & Balance \\
4 & 1500 & 30 & 17.5 & 12.28 & 0.71 & 0.27 & 0.08 & 0.0671 & 0.0712 & Balance \\
\hline
\end{tabular}




\section{Laboratory-scale smelting of limonitic laterite ore from Central Anatolia}

removed by volatilization in the oxide or metallic form during the calcination or prereduction processes, but more experimental work is required to address the issue.

Figure 4 shows the variations in weight and grade of the ferronickel product with excess coal addition. Iron was reduced more extensively with higher coal additions, which increased the mass of the ferronickel but also diluted the nickel grade of the product.

The slags were composed mainly of $\mathrm{Fe}$ and $\mathrm{Si}$ oxides (Table IV). A rough calculation revealed that only about 30\% of the Fe entered the ferronickel at best (experiment no. 4), while the rest remained in the slag. As mentioned before, the low levels of impurities in the alloy were ascribed to the high $\mathrm{FeO}$ content of the slag.

The alumina contents of the slags were 2-3 times higher than expected. The excess alumina entered from the crucible. $\mathrm{CaO}, \mathrm{Cr}_{2} \mathrm{O}_{3}, \mathrm{MgO}$, and $\mathrm{MnO}$ were the other minor oxides in the slag. In addition, $\mathrm{TiO}_{2}, \mathrm{~K}_{2} \mathrm{O}, \mathrm{Sc}_{2} \mathrm{O}_{3}, \mathrm{ZnO}$, and $\mathrm{NiO}$ were present in small quantities. Of these, $\mathrm{Sc}_{2} \mathrm{O}_{3}$ is valuable and commercially important, but was lost in the slag.

Low- and high-magnification SEM micrographs of the solidified slag are shown in Figures $5 \mathrm{a}$ and $5 \mathrm{~b}$, respectively. The slag contained three phases; a dark grey matrix, light grey strips, and a dendritic phase (labelled 1,2, and 3, respectively on Figure 5b). It can be seen that the dendritic phase was mostly composed of fine particles of regular shape. In addition, there were some entrapped ferronickel particles, as seen in Figure $5 \mathrm{c}$. The size of the ferronickel particles rarely exceeded $25 \mu \mathrm{m}$ and was mostly in the 10-20 $\mu \mathrm{m}$ range.

Energy-dispersive spectrometry (EDS) analysis indicated that the matrix was a Si-Fe-Al-rich oxide. Calcium was also incorporated in this phase. The strip-like phase was a Si-Ferich oxide with minor $\mathrm{Mg}$. The dendritic phase was a Cr-AlFe-rich oxide. From the EDS and XRD analyses of the slag, the strip-like phase was found to be a kind of fayalite with the formula $\mathrm{Mg}_{0.26} \mathrm{Fe}_{1.74} \mathrm{SiO}_{4}$. The background was probably ferrosilite with the general formula $\mathrm{FeSiO}_{3}$. The $\mathrm{Cr}$-Al-Fe-rich phase could not be identified.

\section{Losses in the slag}

Metal losses in the slag comprise two types: physical (or mechanical) loss, which is the loss as entrapped ferronickel in the slag (see Figure 5c), and chemical loss, which is the loss as dissolved metal oxide in the slag. Physical and chemical losses of $\mathrm{Fe}, \mathrm{Ni}$, and $\mathrm{Co}$ are discussed below.

\section{Physical losses}

Although the physical losses of $\mathrm{Fe}, \mathrm{Ni}$, and Co were determined individually, these elements were lost in the slag

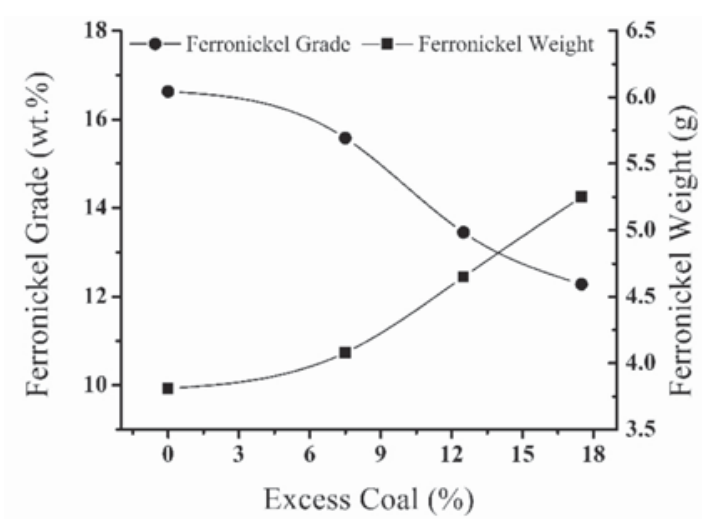

Figure 4-Effect of excess coal on the grade and weight of the ferronickel product

as ferronickel rather than in the pure form. Therefore, consideration of the entrapped ferronickel in the slag, which can be regarded as the sum of $\mathrm{Fe}, \mathrm{Ni}$, and Co physical losses, can be helpful in understanding how the physical loss of each element was affected by the process.

Variations of the physical loss of iron and entrapped ferronickel with excess coal addition are plotted in Figure 6. It is seen that the physical loss of iron increased when more excess coal was added. The total metal (ferronickel) loss in the slag followed the same pattern because iron formed the majority of the physical losses. Hence the effect of coal addition on the ferronickel loss also accounts for the physical loss of iron.

As shown in Figure 7, ferronickel nucleated and grew during the solid-state reduction (prereduction). These nuclei joined together, coalesced, and settled during the subsequent smelting to form a ferronickel pool. Nevertheless, some fine and individual particles, which did not succeed in coalescing with the other nuclei, remained suspended in the silicate matrix and were physically lost in the slag. As the number of nuclei increases, more individual particles are likely to remain in the slag. In addition, the total number of nuclei is directly proportional to the reduction potential during the process, i.e. the coal amount. This could lead to increased physical losses in the slag and could explain why entrapped ferronickel (and physical loss of iron) increased with higher coal additions.

The effect of coal addition on the physical loss of nickel in the slag is shown in Figure 8. The effect may be explained better by considering the average grade of the entrapped ferronickel particles, which is also plotted. The average grade of the entrapped ferronickel can be calculated as follows:

Table IV

XRF analyses of the slags

\begin{tabular}{|c|c|c|c|c|c|c|c|c|c|c|c|}
\hline \multirow[t]{2}{*}{ Exp. no. } & \multicolumn{3}{|c|}{ Experimental conditions } & Slag weight & \multicolumn{7}{|c|}{ Chemical composition of slag (wt\%) } \\
\hline & Temperature $\left({ }^{\circ} \mathrm{C}\right)$ & Retention time (min) & Excess coal $(\%)$ & (g) & $\mathrm{FeO}$ & $\mathrm{SiO}_{2}$ & $\mathrm{Al}_{2} \mathrm{O}_{3}$ & $\mathrm{CaO}$ & $\mathrm{Cr}_{2} \mathrm{O}_{3}$ & $\mathrm{MgO}$ & $\mathrm{MnO}$ \\
\hline $\begin{array}{l}1 \\
2 \\
3 \\
4\end{array}$ & $\begin{array}{l}1500 \\
1500 \\
1500 \\
1500\end{array}$ & $\begin{array}{l}30 \\
30 \\
30 \\
30\end{array}$ & \begin{tabular}{c}
\multicolumn{1}{c}{0} \\
7.5 \\
12.5 \\
17.5
\end{tabular} & $\begin{array}{l}32.12 \\
31.69 \\
31.06 \\
30.28\end{array}$ & $\begin{array}{l}45.46 \\
45.57 \\
45.44 \\
43.64\end{array}$ & $\begin{array}{l}33.82 \\
33.68 \\
33.85 \\
35.41\end{array}$ & $\begin{array}{l}14.26 \\
14.32 \\
13.73 \\
13.85\end{array}$ & $\begin{array}{l}2.46 \\
2.48 \\
2.65 \\
2.7\end{array}$ & $\begin{array}{l}1.43 \\
1.42 \\
1.58 \\
1.64\end{array}$ & $\begin{array}{l}1.28 \\
1.33 \\
1.45 \\
1.46\end{array}$ & $\begin{array}{l}1.05 \\
0.96 \\
1.06 \\
1.08\end{array}$ \\
\hline
\end{tabular}




\section{Laboratory-scale smelting of limonitic laterite ore from Central Anatolia}
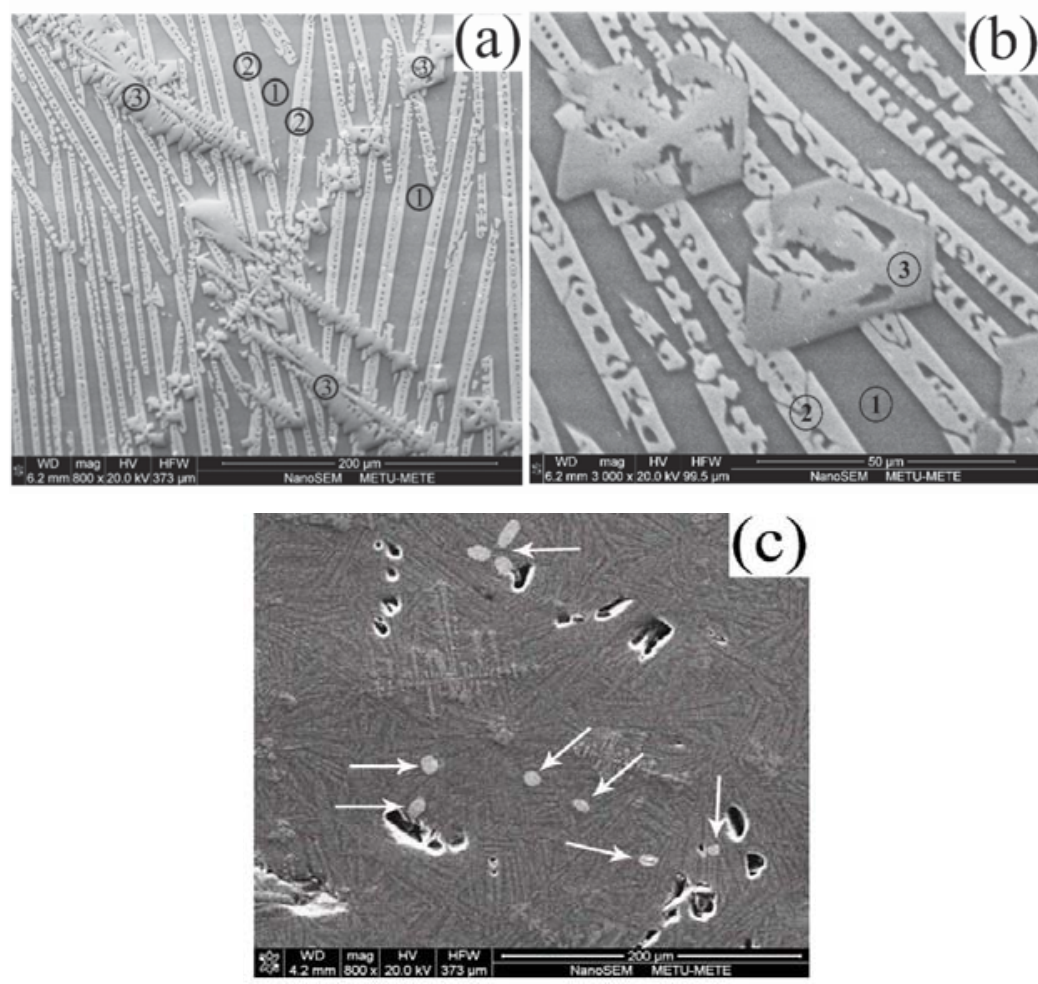

Figure 5-SEM micrographs of the slag; (a) low magnification, (b) high magnification, and (c) entrapped metal particles in slag

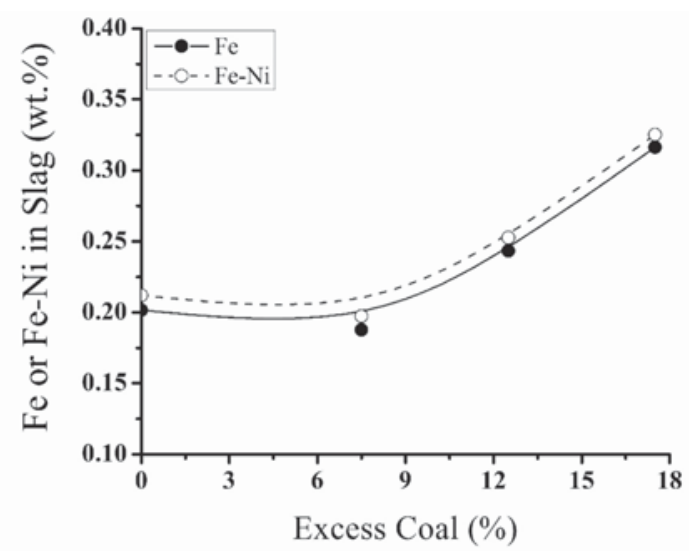

Figure 6-Variation of physical loss of iron and entrapped ferronickel in slag with excess coal addition
Average grade of entrapped particles $(\mathrm{wt} \%)=$

$$
\frac{(\text { Entrapped } \mathrm{Ni}(\mathrm{wt} \%)}{(\text { Entrapped }(\mathrm{Fe}+\mathrm{Ni}+\mathrm{Co})(\mathrm{wt} \%)) \times 100}
$$

Comparison of Figure 8 with Figure 4 shows that the grade of the ferronickel product and the average grade of the entrapped ferronickel changed in the same manner, both decreasing with increasing coal additions. A decrease in the grade of the ferronickel product was accompanied by a corresponding decrease in the average grade of the entrapped ferronickel and physical loss of nickel. It was concluded that physical loss of nickel was directly proportional to the grade of the ferronickel.

Physical loss of cobalt was very low (15-18 ppm) and was not affected significantly by the coal addition. This was attributed to the low cobalt concentration in the ferronickel.

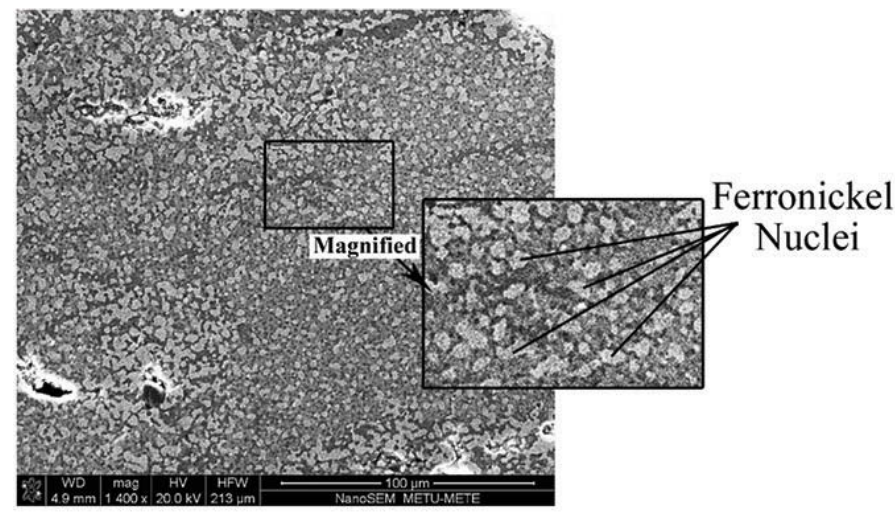

Figure $7-$ Ferronickel nuclei in a particle prereduced at $1100^{\circ} \mathrm{C}$ 


\section{Laboratory-scale smelting of limonitic laterite ore from Central Anatolia}

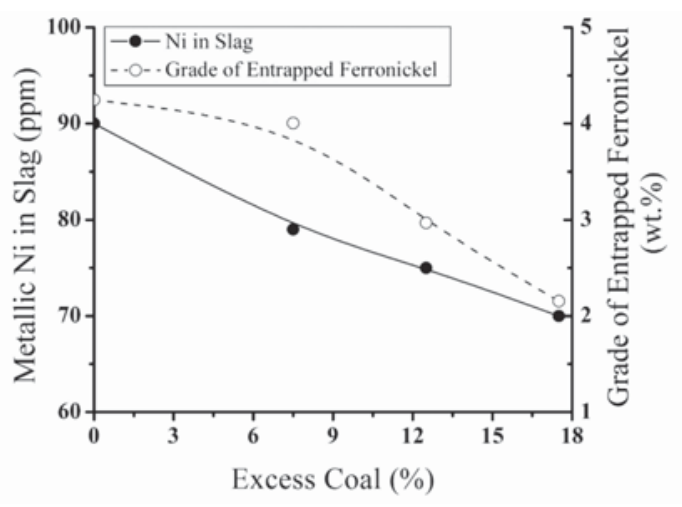

Figure 8-Variation of physical loss of nickel and grade of entrapped ferronickel in slag with excess coal addition

\section{Chemical losses}

Chemical loss of iron, which is in fact the FeO content of the slag, was discussed previously (see Table IV). This section deals with the chemical losses of nickel and cobalt. Chemical losses of nickel and cobalt decreased with increasing coal addition, as illustrated in Figure 9. The effect may be explained as follows. Ferronickel was assumed to be in chemical equilibrium with the slag. Therefore, the activity of a component (Ni, Co) in the slag should be related to its activity in the ferronickel. In addition, the activity of a component in a solution (slag, ferronickel) is proportional to the concentration of that component in the solution.

Consequently, the decreased $\mathrm{Ni}$ and Co chemical losses with increasing coal addition can be ascribed to the lower $\mathrm{Ni}$ and Co concentrations in the corresponding ferronickel product.

\section{Effect of smelting temperature and retention time}

In these experiments, the aim was to determine the minimum required retention time and temperature for the process. The coal addition was chosen to be $12.5 \%$ in excess of the theoretically calculated amount. This coal addition yielded a ferronickel containing about $14.5 \mathrm{wt} \%(\mathrm{Ni}+\mathrm{Co})$, which can be commercially upgraded to $15-20 \mathrm{wt} \%(\mathrm{Ni}+\mathrm{Co})$ after refining.

Two experiments were conducted at $1500^{\circ} \mathrm{C}$ with retention times of 10 minutes and 1 minute. The results (experiments no. 5 and 6, respectively) are summarized in Table V. In comparison with the previous results (experiment 3 ), decreasing the retention time from 30 minutes to 10 minutes and even to 1 minute had no effect on the process,

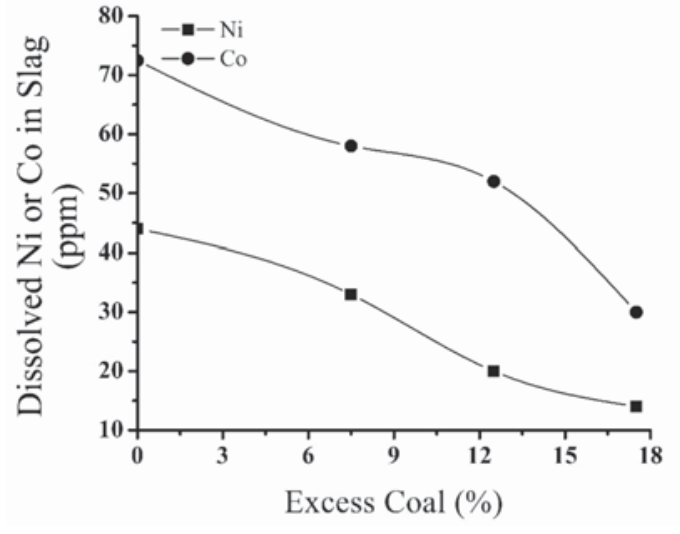

Figure 9-Chemical losses of nickel and cobalt in the slag with excess coal addition

and the same products with the same level of losses were obtained.

In another test, the smelting temperature was lowered to find the minimum required temperature. An experiment was carried out at $1450^{\circ} \mathrm{C}$ with 5 minutes' retention time, but the sample did not melt completely and metal-slag separation was not achieved. The second attempt was made at $1480^{\circ} \mathrm{C}$, but again the sample did not melt completely. Another experiment (experiment 7) was carried out at the mid-point between 1480 and $1500^{\circ} \mathrm{C}$, i.e. $1490^{\circ} \mathrm{C}$. The sample was kept at this temperature for 5 minutes. This time, the sample completely melted and ferronickel was obtained. Therefore, a temperature between 1480 and $1490^{\circ} \mathrm{C}$ was the minimum required temperature for complete smelting of the ore. The results of this experiment are also included in Table $\mathrm{V}$.

There was no meaningful difference between the results of previous experiments at $1500^{\circ} \mathrm{C}$ and the experiment at $1490^{\circ} \mathrm{C}$ with 5 minutes' retention time, particularly in terms of losses in the slag. This showed that separation of the metal from the slag was achieved soon after the temperature reached $1490^{\circ} \mathrm{C}$. Complete metal-slag separation was achieved at $1490^{\circ} \mathrm{C}$, while $1480^{\circ} \mathrm{C}$ was not high enough for complete smelting. The full separation of the metal from the slag was therefore achieved in a relatively short period of time and in a restricted temperature range between 1480 and $1490^{\circ} \mathrm{C}$.

In order to understand what was happening during the course of smelting, the microstructures of the samples which were treated at 1450 and $1480^{\circ} \mathrm{C}$ were examined under SEM.

\section{Table $\mathrm{V}$}

Chemical composition of the ferronickel and slag samples

\begin{tabular}{|c|c|c|c|c|c|c|c|c|c|c|c|c|c|c|}
\hline \multirow[t]{3}{*}{ Exp. no. } & \multicolumn{3}{|c|}{ Experimental conditions } & \multirow{2}{*}{\multicolumn{2}{|c|}{ 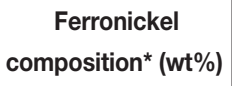 }} & \multirow{2}{*}{\multicolumn{4}{|c|}{ Slag composition (wt\%) }} & \multicolumn{5}{|c|}{ Loss in slag (ppm) } \\
\hline & \multirow[t]{2}{*}{ Temp. $\left({ }^{\circ} \mathrm{C}\right)$} & \multirow[t]{2}{*}{ Retention time (min.) } & \multirow[t]{2}{*}{ Excess coal (\%) } & & & & & & & & nysic & & Che & nical \\
\hline & & & & $\mathrm{Ni}$ & Co & $\mathrm{FeO}$ & $\mathrm{SiO}_{2}$ & $\mathrm{Al}_{2} \mathrm{O}_{3}$ & $\mathrm{CaO}$ & $\mathrm{Ni}$ & Co & $\mathrm{Fe}$ & $\mathrm{Ni}$ & Co \\
\hline $\begin{array}{l}5 \\
6 \\
7\end{array}$ & $\begin{array}{l}1500 \\
1500 \\
1490\end{array}$ & $\begin{array}{c}10 \\
1 \\
5\end{array}$ & $\begin{array}{l}12.5 \\
12.5 \\
12.5\end{array}$ & $\begin{array}{l}13.26 \\
13.18 \\
12.89\end{array}$ & $\begin{array}{l}0.71 \\
0.66 \\
0.73\end{array}$ & $\begin{array}{l}44.3 \\
45.0 \\
46.1\end{array}$ & $\begin{array}{l}35.4 \\
35.6 \\
34.5\end{array}$ & $\begin{array}{l}13.5 \\
12.4 \\
12.0\end{array}$ & $\begin{array}{l}2.5 \\
2.6 \\
2.7\end{array}$ & $\begin{array}{l}75 \\
74 \\
92\end{array}$ & $\begin{array}{l}19 \\
18 \\
21\end{array}$ & $\begin{array}{l}2339 \\
2927 \\
2458\end{array}$ & $\begin{array}{l}17 \\
20 \\
12\end{array}$ & $\begin{array}{l}25 \\
26 \\
27\end{array}$ \\
\hline
\end{tabular}

* The balance is iron and minor elements 


\section{Laboratory-scale smelting of limonitic laterite ore from Central Anatolia}

Their microstructures (Figure 10) were composed of ferronickel aggregates within a slag matrix. The microstructure of the slag matrix was very similar to that observed in the completely melted samples (see Figure $5 \mathrm{a}$ ), indicating that the slag was molten at these temperatures $\left(1450\right.$ and $\left.1480^{\circ} \mathrm{C}\right)$. These results suggested that the incomplete metal-slag separation at 1450 and $1480^{\circ} \mathrm{C}$ stemmed from the high melting point of the ferronickel relative to that of the slag. In fact, the slag was molten but the ferronickel was not.

The impact of the low-melting slag on the process was twofold. Since the slag melted before the ferronickel, ferronickel particles (nuclei) could move freely in the liquid slag and easily coalesce during heating. The second impact was that the slag should be heated to well above its liquidus temperature on order to melt the ferronickel as well. The high superheat resulted in an adequately fluid slag. This enabled a quick and complete metal-slag separation within a restricted temperature range between 1480 and $1490^{\circ} \mathrm{C}$.

\section{Nickel recovery}

Nickel losses can simply be calculated as follows:

$$
\text { Nickel losses }(\%)=\frac{\left(W_{\text {slag }} \times\left(L_{c h}^{N i}+L_{p h}^{N i}\right)\right)}{\text { Nickel input }} \times 100
$$

where $L_{c h}^{N i}$ and $L \frac{N i}{p h}$ are weight percentages of the dissolved (chemical loss) and the metallic nickel (physical loss) in slag, respectively. In the current study, the nickel concentration of the slags was about $0.01 \%$. Under these circumstances, $0.4-0.7 \%$ of the nickel was lost in the slag, implying that recoveries of about $99.5 \%$ were achieved. The nickel concentration of industrial slags, however, is typically $0.1-0.2 \mathrm{wt} \%$ and the nickel recovery thus lies between $90-95 \%$. That is, $5-10 \%$ of the nickel is lost in industrial slags.
For further studies, a few kilograms of industrial ferronickel and slag were obtained from the Larco smelter in Greece. Sivrihisar laterite and Greek laterites (Halikia, Skartados, and Neou-Syngouna, 2002; Zevgolis et al., 2010) are alike in mineralogical and compositional terms.

The chemical composition of the Larco ferronickel and slag, as given in Table VI, was similar to those obtained experimentally. The main difference was the higher alumina content of the experimental slags, which was ascribed to the slag-crucible interaction in the experiments.

SEM micrographs of the Larco slag are shown in Figure 11. Being analogous to the experimental slags (see Figure 5), the Larco slag was also composed of three phases: a Si-Al$\mathrm{Fe}-\mathrm{Ca}$-rich matrix, $\mathrm{Si}-\mathrm{Fe}-\mathrm{Mg}$-rich stripes, and $\mathrm{Cr}$-Al-Fe-rich particulates of regular shape. Entrapped ferronickel particles were also observed in the slag (Figure 11b). They varied from only a few micrometres to more than $350 \mu \mathrm{m}$ in size. Physical and chemical losses in the industrial slag are given in Table VII. The chemical losses were in the same range as the experimental results, but the physical losses were much greater in the industrial slag. The difference arose from conditions prevailing in arc furnaces where, in contrast to the experimental set-up, the ore is smelted on a very large scale and the system is dynamic. Slag movements do not provide the quiescent conditions required for metal particles to coalesce.

A microstructural study of the Larco slag further revealed that the $\mathrm{Cr}$-rich particles may, to a large extent, have been responsible for the physical losses of fine $\mathrm{Fe}$-Ni particles in the slag. With the exception of some large entrapped ferronickel particles, in most of the cases fine particles were entrapped among the $\mathrm{Cr}$-rich particles (Figure 12). Some of the ferronickel particles were deformed between the $\mathrm{Cr}$-rich particles and some, semicircular in shape, adhered to these particles, indicating that the $\mathrm{Cr}$-rich particles were solid when
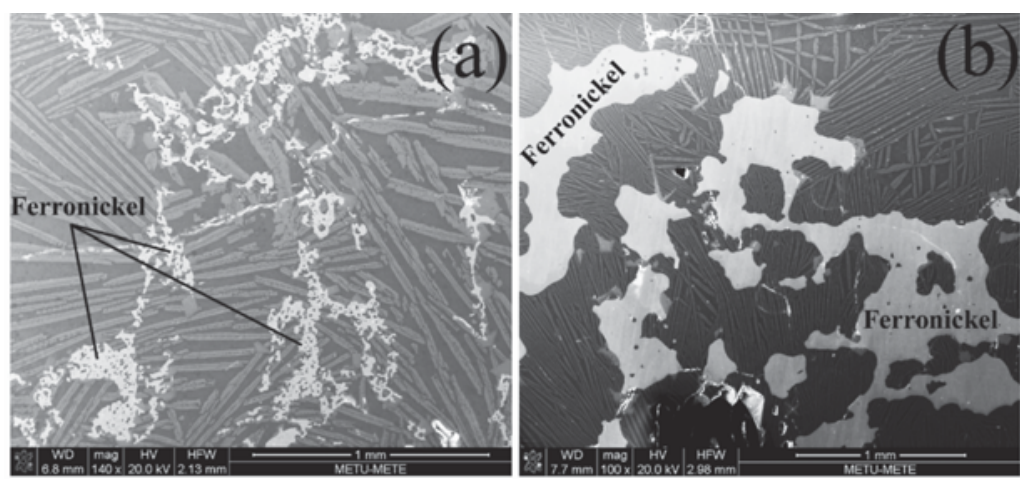

Figure $10-\mathrm{SEM}$ micrographs of the sample heated at (a) $1450^{\circ} \mathrm{C}$ and (b) $1480^{\circ} \mathrm{C}$

Table VI

Chemical composition of the Larco ferronickel and slag

\begin{tabular}{|c|c|c|c|c|c|c|c|c|c|c|}
\hline \multirow[b]{2}{*}{$\mathrm{Ni}$} & \multicolumn{4}{|c|}{ Ferronickel $^{\star}$} & \multicolumn{6}{|c|}{ Slag } \\
\hline & Co & As & S & C & $\mathrm{FeO}$ & $\mathrm{SiO}_{2}$ & $\mathrm{Al}_{2} \mathrm{O}_{3}$ & $\mathrm{CaO}$ & $\mathrm{Cr}_{2} \mathrm{O}_{3}$ & $\mathrm{MgO}$ \\
\hline 14.8 & 0.47 & 0.06 & 0.21 & 0.05 & 43.7 & 33.5 & 8.8 & 4.4 & 4.3 & 3.7 \\
\hline
\end{tabular}

* The balance is iron and traces of e.g. P, Al, Cu, Si 


\section{Laboratory-scale smelting of limonitic laterite ore from Central Anatolia}

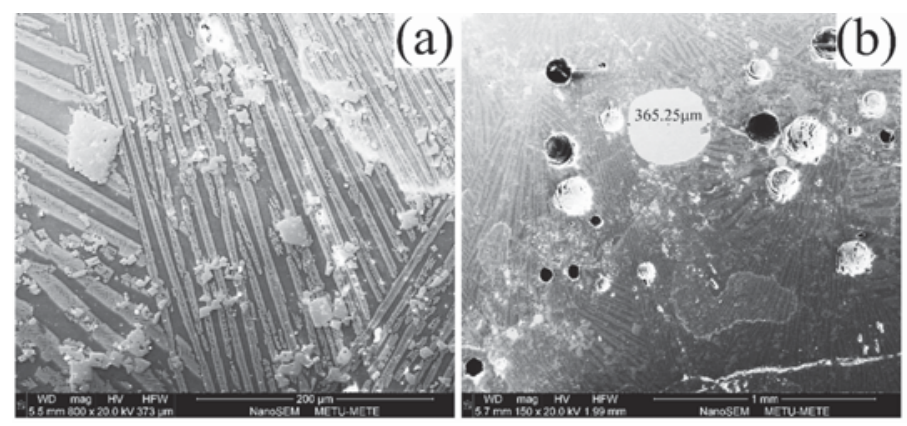

Figure 11-SEM micrographs of the Larco slag

\begin{tabular}{|c|c|c|c|c|}
\hline \multicolumn{5}{|c|}{$\begin{array}{l}\text { Physical and chemical losses in industrial slag from } \\
\text { Larco smelter }\end{array}$} \\
\hline \multicolumn{3}{|c|}{ Physical loss in slag (ppm) } & \multicolumn{2}{|c|}{ Chemical loss in slag (ppm) } \\
\hline $\mathrm{Fe}$ & $\mathrm{Ni}$ & Co & $\mathrm{Ni}$ & Co \\
\hline 4699 & $760^{*}$ & 32 & 60 & 58 \\
\hline
\end{tabular}

* Higher nickel losses (1920 ppm) were reported by the smelter. The difference may be related to sampling.

they came into contact with the liquid ferronickel droplets. The high-melting-point $\mathrm{Cr}$-rich particles were suspended throughout the slag and acted as traps for fine ferronickel particles.

\section{Conclusions}

The pyrometallurgical extraction of nickel from a Turkish laterite ore was investigated. The main findings of this research work are as follows.

> A ferronickel of acceptable grade was smelted from low-grade limonitic laterite ore. However, more experimental work is required to address the arsenic content in the product

> During the smelting, almost all of the nickel, 90-95\% of the cobalt, and $30-40 \%$ of the iron in the ore were reduced to yield a ferronickel containing from $12-18 \%$ $(\mathrm{Ni}+\mathrm{Co})$

$>$ Coal addition was the key parameter that controlled the grade of the product ferronickel. Increased coal additions encouraged iron reduction, which in turn diluted the product ferronickel and lowered its grade

> Coal addition also controlled the physical loss of ferronickel. The higher the coal addition, the higher the physical loss

> Smelting of limonitic laterite ore resulted in a slag with a lower melting temperature than that of the ferronickel. Accordingly, the melting point of the ferronickel determined the minimum processing temperature. The minimum temperature for successful smelting was found to be in the range $1480-1490^{\circ} \mathrm{C}$. A short retention time (5 minutes) was sufficient to achieve complete metal-slag separation at this temperature

> The physical loss of iron was proportional to the coal addition, whereas the physical losses of nickel and cobalt were directly proportional to the ferronickel grade. Chemical losses of $\mathrm{Fe}, \mathrm{Ni}$, and Co decreased when more coal was added to the charge.

> The high-melting-point $\mathrm{Cr}$-rich particles suspended in the slag were the main source of the physical losses in the industrial slag.

\section{Acknowledgement}

The authors would like to thank the Scientific Research Projects (BAP) Department of the Middle East Technical University for the financial support under project no. BAP03-08-2012-002. The authors also wish to express their thanks to the META Nickel Cobalt Company of Turkey for supplying the lateritic ore. The LARCO smelter in Greece is acknowledged for supplying the ferronickel slag.
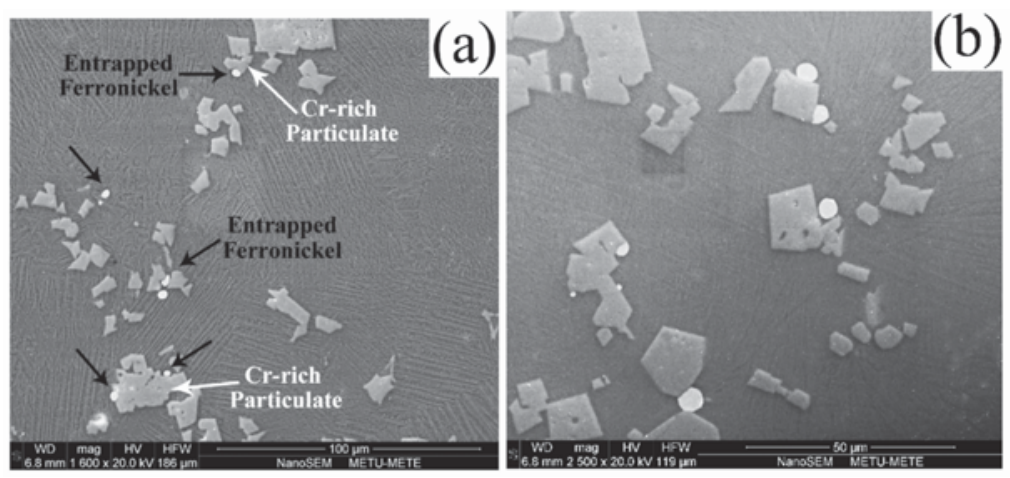

Figure 12-(a) Low- and (b) high-magnification SEM micrographs of ferronickel particles entrapped among the Cr-rich particulate phase 


\section{Laboratory-scale smelting of limonitic laterite ore from Central Anatolia}

\section{References}

CANTERFoRd, J.H. 1975. The treatment of nickeliferous laterites. Minerals Science and Engineering. vol. 7, no. 1. pp. 3-17.

Halikia, I., Skartados, K., and Neou-Syngouna, P. 2002. Effect of reductive roasting on smelting characteristics of Greek nickel laterites. Mineral Processing and Extractive Metallurgy, vol. 111, no. 3. pp. 135-142.

Keskinkiliç, E., Pournaderi, S., Geveci, A., and Topkaya, Y. 2012. Calcination characteristics of laterite ores from the central region of Anatolia. Journal of the Southern African Institute of Mining and Metallurgy, vol. 112, no. 10. pp. 877-882.

Kinson, K., DicKeson, J.E., and Belcher, C.B. 1968. The determination of metallic iron, nickel and cobalt in reduced ores and oxides. Analytica Chimica Acta, vol. 41. pp. 107-112.

MudD, G.M. 2010. Global trends and environmental issues in nickel mining: Sulfides versus laterites. Ore Geology Reviews, vol. 38, no. 1. p. 9-26.

Pournaderi, S., Keskinkiliç, E., Geveci, A., and TopkAYa, Y. 2014. Reducibility of nickeliferous limonitic laterite ore from Central Anatolia. Canadian Metallurgical Quarterly, vol. 53, no. 1. pp. 26-37.

ReinecKe, I.J. and LAGENDIJK, H. 2007. A twin-cathode dc arc smelting test at Mintek to demonstrate the feasibility of smelting FeNi from calcine prepared from siliceous laterite ores from Kazakhstan for Oriel Resources plc. Infacon XI, Proceedings of the 11th International Ferroalloys Congress, New Delhi, India, 18-21 February 2007. Indian Ferro Alloy
Producers' Association. pp. 781-797.

http://www.mintek.co.za/Pyromet/Files/2007Reinecke.pdf

NoRGATE, T. and JAHANSHAHI, S. 2010. Low grade ores - smelt, leach or concentrate? Minerals Engineering, vol. 23, no. 2. pp. 65-73.

Voermann, N.T., GerRitsen, T., CAndy, I., Stober, F., and Matyas, A. 2004. Developments in furnace technology for ferronickel production. Infacon $X$, Proceedings of the Tenth International Ferroalloys Congress, Cape Town, South Africa, 1-4 February 2004. pp. 455-465. http:// http://www.pyro.co.za/InfaconX/069.pdf

WalKer, C., Voermann, N., CANDY, I.M., and Wasmund, B. 2009. Nickel laterite rotary kiln - electric furnace plant of the future. Proceedings of Pyrometallugy of Nickel and Cobalt, Sudbury, Ontario, Canada, August 2009. CIM, Montreal. pp 33-50.

Warner, A. E. M.. Díaz, C.M., Dalvi, A.D., Mackey, P.J., and Tarasov, A.V. 2006. JOM world nonferrous smelter survey, part III: nickel: laterite. JOM, vol. 8, no. 4. pp. 11-20

ZEvGoLIS, E.N. 2004. The evolution of the Greek ferronickel production process. Proceedings of the International Laterite Nickel Symposium, Charlotte, NC, USA. Imrie, W.P., Lane, D.M., and Barnett, S.C.C. (eds.).Wiley, New York. pp. 619-632.

Zevgolis, E.N., Zografidis, C., Perraki, T., and Delvin, E. 2010. Phase transformations of nickeliferous laterites during preheating and reduction with carbon monoxide. Journal of Thermal Analysis and Calorimetry, vol. 100, no. 1. p. 133-139. 